\begin{tabular}{|c|c|}
\hline \multirow{3}{*}{ 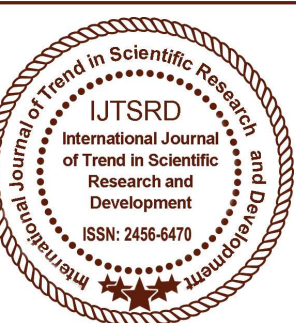 } & $\begin{array}{l}\text { International Journal of Trend in Scientific } \\
\text { Research and Development (IJTSRD) }\end{array}$ \\
\hline & International Open Access Journal \\
\hline & ISSN No: 2456 -6470 | www.ijtsrd.com | Volume - 2 | Issue - 3 \\
\hline
\end{tabular}

\title{
Parallel between Comedy of Humours and Comedy of Manners
}

\author{
T. Poornima, M. Priyanga, K. Swarnamuki \\ M.A English, Nadar Saraswathi College of Arts And Science, Theni, Tamil Nadu, India
}

\begin{abstract}
The comedy of humour which deals largely with exaggerated types of humour was one which adumbrated in the and in Ralph Roister Dolster and then after a not very glorious career was rendered popular by Jonson in Every Man in His Humour. All comedy is it of humours or of romance of manner, deals with types of character than with personalities. But the comedy of humours deals with types which are more exaggerated than the types in Shakespeare comedy.
\end{abstract}

Keyword: Restoration Comedy, humour, Jonson's Comedy

The comedy of humours was a genre of dramatic comedy that focuses on a character or range of characters, each of whom exhibits two or more overriding traits or 'humours' that dominates their personality, desires and conduct. The comedy of manners was a form of comedy that satirizes the manners and affectations of contemporary society and questions societal standards. A comedy of manners often sacrifices the plot, which usually centers on some scandal, to witty dialogue and sharp social commentary. Oscar Wilde's play, The Importance of Being Earnest (1895), which satirized the Victorian morality of the time, is one of the bestknown plays of this genre.

This comic technique may be found in Aristophanes, but the English playwrights Ben Jonson and George Chapman popularized the genre in the closing years of the sixteenth century. In the latter half of the seventeenth century, it was combined with the comedy of manners in Restoration comedy. The Johnsonian comedy of humours in the first place is

marked off from the romantic drama by its intense realism. It was Johnson's boast and virtue that he drew comedy down from the improbable realms of romantic colouring to the levels of ordinary existence where he could utilize. Jonson's great merit lies in the fact that he drew comedy down to real life, presenting classes and the follies of contemporary London at a time when there was a fear of comedy's vanishing altogether into those fantastic and impossible realms of make believe which had been popularized by Shakespeare.

As has been well remarked Realism added to intensified humours treated in a satirical spirit was first given to the theatrical world by Jonson. Some critics however go too far and say that Jonson dealt with the manner as the ancestor of the Restoration comedy. But to be quite frank Jonson deals hardly affectation of the world but with the follies of particular men or of particular groups of men. His comedy was distinguished from the comedy of manners by the fact that it puts its stress not on manners but on natural idiosyncrasies. In only two things does Jonson stand connected with the later comedy of manners in his realism and in his satire and their find that the realism and satire of Jonson are definitely separated at many points from the similar qualities that occasionally appear in the Restoration dramas?

The comedy of manners as its name suggests is an entirely different species from the comedy of Jonson. There may be humours in the plays of the Restoration dramatists but those humours are not stressed to the same extent as they are in Jonson work and there was moreover a marked change in their conception. In Jonson as they have seen the 
humour are exaggerated traits of character. The very names of his dramatist personae demonstrate this Deliro, Sordido, Fungoso Shift, in Every man in his humour: Volpone, Corbaccio, in The Fox these know the tendency of creative activity. In the comedy of manners are derived from convention follies and usage of social life instead of individuals.

They have something more in the term comedy of manners that at first sight meets the eye. Manners may mean simply the way of men in which case it will apply to the Jonsonian comedy as to that of the Restoration. It may mean the conventions of an artificial society, and it may mean something brilliant about men and women not a humour derived from natural idiosyncrasy but a grace or a habit of refined culture. The manner and the characters of the Restoration plays differ marked from the matter and the characters of the comedy of Jonson. In a scene however both are like. Not a single one of the true Restoration comedies of manners was set out of the bounds of London. The dramatists clung rigidly to the circle of London society.

The restoration dramatist also shared that satirical spirit of Jonson, but in sharing that spring, they altered it. Jonson's dramas had been built on satire which was an integral part of the comedy of manners. This satire however in its reappearance was totally changed. It was no longer the satire of the self-opinionated and slightly pessimistic individuals, as with Jonson but the gentle satire of the fine world at the follies of those who strove to enter into elegant circle. The comedy of manners also unlike Jonson, utilized the power of wit. His satire of exaggeration. The comedy of manners neglected this.

The comedy of manner was realistic but not in the manners that Jonson's plays were realistic. In Jonson works there was a decided attempt to display through the types traits of contemporary life there was a mass of topical allusion and the subjects are often from real life but it is a real artificial and still further it is the airier, what they might almost call the spiritual parts of real life.

\section{References}

1) Khandelwal K.N. BENJONSON'S "EVERY MAN IN HIS HUMOUR" Published by Lakshmi Narayan Agarwal Educational publishers

2) https://en.wikipedia.org/wiki/Comedy_of_manne rs

3) https://en.wikipedia.org/wiki/Comedy_of_humou rs

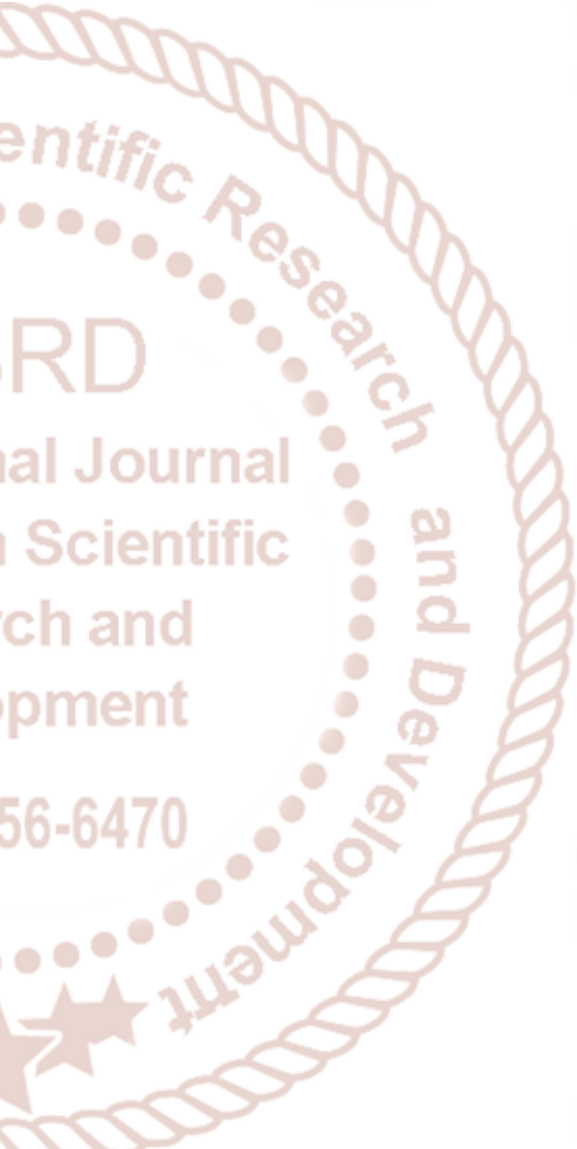

